\title{
Spawning and recruitment of the bluehead wrasse Thalassoma bifasciatum in Barbados, West Indies
}

\author{
I. Hunt von Herbing ${ }^{1, *}$, W. Hunte ${ }^{1,2}$ \\ ${ }^{1}$ Bellairs Research Institute of McGill University, St. James, Barbados, West Indies \\ ${ }^{2}$ Biology Department, University of the West Indies, Cave Hill, Barbados, West Indies
}

\begin{abstract}
Spawning and recruitment periodicity and post-recruitment mortality were investigated in the bluehead wrasse Thalassoma bifasciatum on fringing reefs on the west coast of Barbados by direct census and by otolith dating techniques. Spawning was seasonal, occurring primarily between January and August. Recruitment was seasonal, and was significantly correlated with spawning with time lags of 1 and 2 mo. This is consistent with the $45 \mathrm{~d}$ (range 33 to $64 \mathrm{~d}$ ) larval life of $T$. bifasciatum, and suggests that seasonal variation in spawning is the principal factor driving seasonal variation in recruitment. Spawning frequency was higher around new and full moons (spring tides) than around first and last quarters (neap tides), but recruitment did not differ significantly with lunar phase. Daily spawning was more frequent during ebb tides than flood tides, with peak spawning occurring near the beginning of ebb tide. Surface currents on the study reefs were offshore on $96 \%$ of the 94 occasions monitored, regardless of tidal phase. Surface currents at ebb tide were faster than at flood tide, and ebb tide currents were faster during spring tides than neap tides. The data suggest that both daily and lunar spawning cycles are influenced by daily and lunar variation in the speed of offshore currents. Population densities on all reefs had returned to pre-recruitment levels within 3 mo of the end of seasonal recruitment. Monthly mortality (\% dying per month) on each study reef during the post-recruitment period was correlated with population density on that reef at the start of the month. This may suggest that post-recruitment mortality is density-dependent, but it could result from the covariance of density with age. However, the mean monthly mortality rate over the post-recruitment period on each reef was significantly correlated with recruitment strength to that reef. This suggests that post-recruitment mortality is density-dependent, and hence that post-recruitment processes influence the population dynamics of bluehead wrasse in Barbados.
\end{abstract}

\section{INTRODUCTION}

Most coral reef fishes are demersal as juveniles and adults, but have a planktonic larval phase which varies interspecifically between ca $1 \mathrm{wk}$ and $3 \mathrm{mo}$ (Brothers et al. 1976, 1983, Victor 1986a, Wellington \& Victor 1989). Many species show seasonal, lunar or semi-lunar cycles in spawning frequency (Munro et al. 1973, Johannes 1978, MacFarland et al. 1985, Robertson et al. 1988. Côté \& Hunte 1989). A prevailing view is that the fish spawn at times and locations which facilitate rapid transport of eggs and larvae off reefs (Robertson \& Hoffman 1977, Tribble 1982, Doherty 1983a, b), presumably to minimise predation by reef-associated organisms (Johannes 1978). However, Shapiro et al. (1988) emphasised that simultaneous measurements of

- Present address: Biology Department, Dalhousie University, Halifax, Nova Scotia, Canada B3H 4JI spawning and water movement have not been conducted, and suggested that bluehead wrasse Thalassoma bifasciatum in Puerto Rico do not spawn at locations which maximise egress of eggs from reefs.

Cyclical spawning might be expected to strongly influence the timing and strength of recruitment from the plankton to reefs. However, an emerging view is that planktonic processes are primarily responsible for variation in recruitment and that recruitment variation is the principal factor driving the dynamics of the demersal populations (Williams 1980, Doherty 1982, 1983b, Doherty \& Williams 1988, Pitcher 1988). For example, Victor $(1983,1986 \mathrm{~b})$ believed that bluehead wrasse in Panama had neither seasonal nor lunar spawning cycles, and observed that recruitment was episodic and reflected in the subsequent population size of adults. He therefore concluded that planktonic processes drove both recruitment variation and adult population dynamics. More recently, Robertson et al. 
(1988) have shown that variation in the timing and strength of recruitment in damselfish Stegastes partitus in Panama is caused by variation in spawning frequency, and Hunte \& Côté (1989) have suggested that the population dynamics of blennies Ophioblennius atlanticus in Barbados is influenced primarily by conspecific competitive interactions following recruitment (see also Smith 1978, Gladfelter \& Gladfelter 1979, Shulman 1984, 1985 and Jones 1987 for the importance of post-recruitment processes).

The purpose of this paper is to address 3 issues on spawning and recruitment of the bluehead wrasse in Barbados: (1) Is spawning cyclical, if so over what time scale, and does it occur when offshore currents are fastest? (2) Is recruitment variation coupled to spawning variation? (3) Do post-recruitment processes influence population dynamics - or more specifically, is post-recruitment mortality density-dependent?

\section{METHODS}

The bluehead wrasse Thalassoma bifasciatum is a sequential hermaphrodite found commonly on coral reefs of the Caribbean and tropical Western Atlantic. It consists of initial phase (IP) individuals (males and hermaphrodite females) and terminal phase (TP) individuals (primary and secondary males), and is a pelagic spawner. TP males maintain territories during the daily spawning period and pair-spawn singly with females. IP males form groups of a few to several dozen individuals and group-spawn with one or more females (Warner et al. 1975).

Spawning and recruitment of the bluehead wrasse was studied from September 1984 to October 1985, on 7 large fringing reefs along the west coast of Barbados, West Indies (see Hunt von Herbing 1988), Preliminary observations indicated that $98 \%$ of daily spawning in Barbados occurs between 11:00 and 15:00 h. To investigate lunar and seasonal variation in spawning, spawning events were monitored twice a week per reef on 2 of the fringing reefs (North Bellairs and Heron Bay) for 14 mo. On each reef, 5 transects parallel to shore were surveyed and the number of group spawns and pair spawns occurring within a $2 \mathrm{~m}$ radius of the transect line were recorded. Each transect was $150 \mathrm{~m}$ long and required 10 min to swim. On each sampling day, 1 of the 4 spawning hours was randomly chosen to conduct the 50 min transect swim.

To investigate effects of surface currents on spawning frequency, current speed and direction were measured on alternate weeks over the North Bellairs and Heron Bay reefs throughout the 14 mo study period. Measurements were taken twice a day, or once a day on consecutive days, close to the turn of high and low tides. Current speed and direction were determined by tracking a Perspex drogue suspended at $1.0 \mathrm{~m}$ depth near the central onshore point of the reef, and compass sightings were taken from the drogue to points on shore every 5 min for $1 \mathrm{~h}$.

To investigate effects of tidal stage (i.e. ebb and flood tide) on daily spawning frequency, a 2 wk experiment was conducted in May 1985 on North Bellairs reef. Spawning frequency was monitored by 4 observers each day for 30 min each hour throughout the $4 \mathrm{~h}$ spawning period at each of 15 spawning sites on the reef. The proximity of spawning sites ensured that a single observer could monitor more than one site simultaneously. The data were used to determine whether the daily peak spawning was influenced by tidal stage. Tidal data were obtained from the Barbados Port Authority.

Variation in recruitment was investigated by use of otoliths, since Victor (1982) has demonstrated the presence of daily rings and settlement marks on otoliths of Thalassoma bifasciatum. About 50 fish were sampled monthly from Heron Bay reef between October 1984 and October 1985, using a 21 glass jar contajning a crushed sea urchin Diadema antillarum placed at 5 sites across the reef. The technique was size-selective, ca $98 \%$ of the fish caught being $>30 \mathrm{~mm}$ standard length (SL). Fish of $30 \mathrm{~mm}$ are about $3 \mathrm{mo}$ old, and sexual maturity occurs over the size range 30 to $40 \mathrm{~mm}$ for bluehead wrasse in Barbados. Two pairs of the larger otoliths (sagittae and lapillae) were removed from the ear canals of each fish caught ( $N=790)$ The otoliths were rinsed in 90 to $100 \%$ ethanol and then cleared for $24 \mathrm{~h}$ in xylene. Pairs of otoliths were mounted with mounting medium on glass slides and viewed with polarization under $400 \times$ magnification with a compound microscope. The date of settlement from the plankton was calculated by subtracting the number of daily increments between the settlement mark and the perimeter of the otolith (including the increments within the settlement band; this gives the number of days since settlement) from the collecting date. These data were used to characterise seasonal and lunar variation in recruitment. Fertilisation dates were also determined from the monthly otolith samples (see Keener et al. 1988). These were calculated by subtracting the larval life in days (including hatching time - ca $24 \mathrm{~h}$ ) from the settlement date.

Population density was censused once per. month on 5 reefs (North Bellairs, Paynes Bay, Golden Palms, Sandridge, and Greensleeves), and once per. week on Heron Bay. Densities were measured by swimming slowly along three $50 \mathrm{~m}$ transects holding a $1 \mathrm{~m}$ expandable ruler and counting the number of initial phase and terminal phase individuals $>30 \mathrm{~mm}$ within $0.5 \mathrm{~m}$ on either side of the transect line (see Miller \& 
Hunte 1987 for discussion of technique), Fish $<30 \mathrm{~mm}$ frequently hide and are difficult to detect during censuses. Given the size range at sexual maturity (30 to $40 \mathrm{~mm}$ ), fish $>30 \mathrm{~mm}$ are older juveniles/sub-adults and adults. For convenience, they are subsequently referred to as adults throughout this study. Densities were measured outside of the daily spawning period to avoid bias caused by individuals moving to spawning sites.

\section{RESULTS}

\section{Seasonal spawning}

The number of spawning events (pair and group) observed on the 2 study reefs (North Bellairs, Heron Bay) between October 1984 and October 1985 was not uniformly distributed across months (KolmogorovSmirnov 1-sample test, $D=0.19, \mathrm{p}<0.01$ ), spawning occurring primarily between January and August (Fig. 1a). Seasonal variation in the number of spawns did not differ between reefs (Kolmogorov-Smirnov 2sample test, $D=0.33, p>0.05)$. Of all spawns observed, $71 \%$ were group spawns, and seasonal vari-

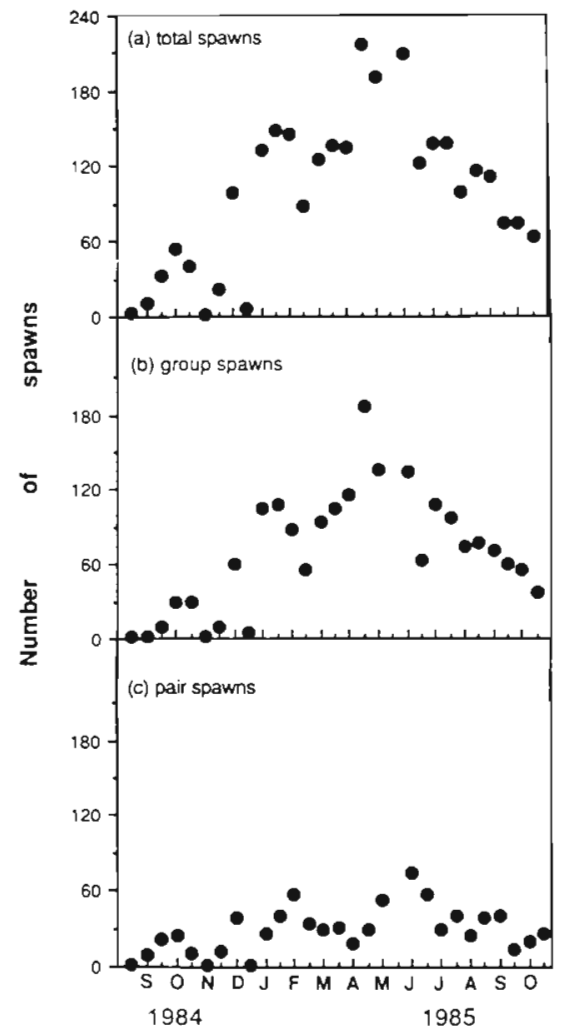

Fig. 1. Thalassoma bifasciatum. Total number of spawning events, number of group spawning events and number of pair spawning events vs time of year on North Bellairs and Heron Bay reefs (Barbados) combined ation in group spawning was more marked than in pair spawning (Fig. 1b, c).

The increase in spawning between January and August could have resulted from more adult fish being on the reefs to spawn in those months and/or from an increase in spawning frequency per fish. Mean monthly adult density was significantly lower between January and August (North Bellairs mean $0.89 \mathrm{~m}^{-2}$ Heron Bay mean $1.38 \mathrm{~m}^{-2}$ ) than between September and December (North Bellairs mean $1.17 \mathrm{~m}^{-2}$; Heron Bay mean $1.67 \mathrm{~m}^{-2}$; for North Bellairs, $t=2.29$ $\mathrm{p}<0.05$; for Heron Bay, $t=2.40, \mathrm{p}<0.05$; see also Fig. 8 ); i.e. adult density was lowest when the number of spawning events was highest.

Spawning frequency per fish (number of monthly spawns divided by fish density in that month) was considerably higher between January and August than between September and December (Fig. 2a), for both IP fish in group spawns (Fig. 2b) and TP fish in pair spawns (Fig. 2c).

Seasonal variation in spawning during 1984 was investigated using the monthly distribution of fertilisation dates as determined by otolith dating (see Keener et al. 1988 for methodology). Fertilisation dates in 1984 were not uniformly distributed across months (Kol-

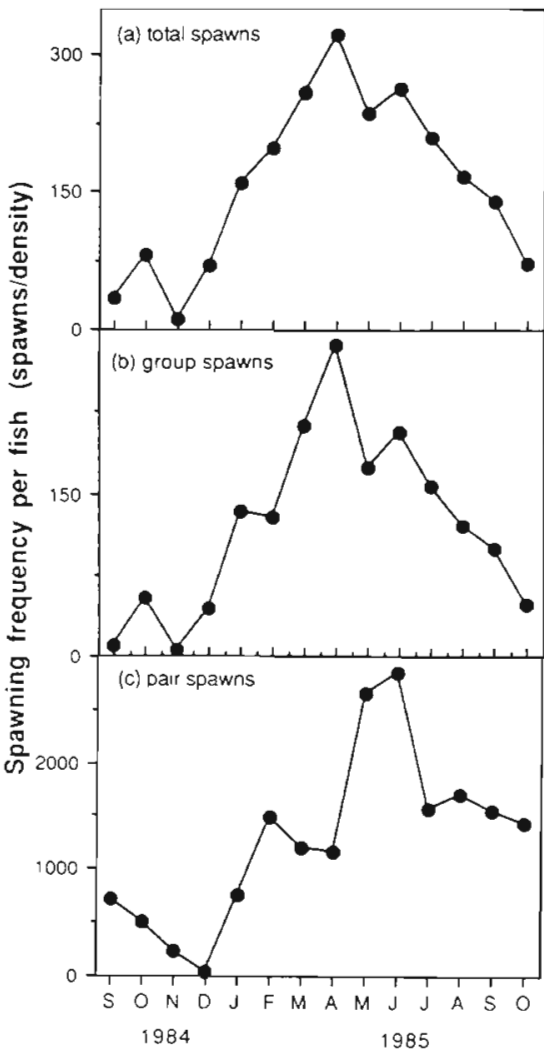

Fig. 2. Thalassoma bifasciatum. Index of spawning frequency per fish (no. of spawns per month/fish density in the month) on North Bellairs and Heron Bay reefs, Barbados. Data are monthly means from the 2 reefs 


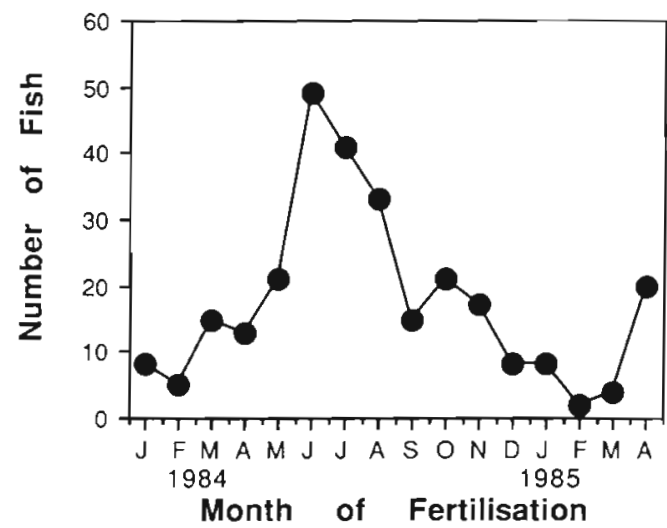

Fig. 3. Thalassoma bifasciatum. Distribution of fertilisation dates on Heron bay reef between January 1984 and April 1985

mogorov-Smirnov 1-sample test, $D=0.17, \mathrm{p}<0.05)$, most fertilisation occurring between March and November (Fig. 3). The distribution of fertilisation dates in 1984 is similar to the distribution of spawning events in 1985 (Fig. 1), suggesting inter-annual consistency in seasonal spawning cycles.

\section{Lunar spawning}

The mean number of spawns observed in each lunar phase between January and August 1985 on North Bellairs and Heron Bay reefs is shown separately for group and pair spawning in Fig. 4. The frequency of pair spawning did not differ significantly between lunar phases (Kruskal-Wallis ANOVA, $H=1.82$, $\mathrm{p}>0.05$; Fig. 4). However, group spawning appeared to be more frequent at new and full moons (spring tides) than at first and last quarters (neap tides; Fig. 4). When spawns were pooled into spring and neap tides, the mean number of group spawns occurring during spring tides between January and August was greater

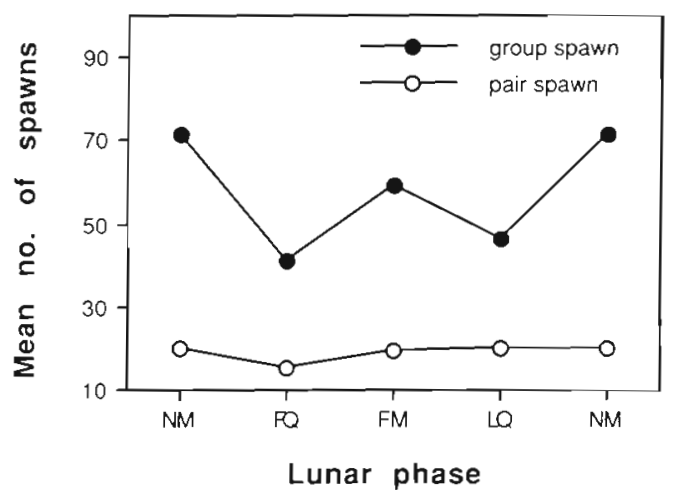

Fig. 4. Thalassoma bifasciatum. Mean number of group and pair spawns in each lunar phase between January and August 1985 on Heron Bay and North Bellairs reefs. NM; new moon;

FQ: first quarter; FM: full moon; LQ: last quarter than that during neap tides (Mann-Whitney, $U=90$, $\mathrm{p}<0.05$ )

\section{Daily spawning}

The number of spawning events occurring at each stage of the daily tidal cycle was monitored at North Bellairs reef for $2 \mathrm{wk}$ in April 1985. Neither group nor pair spawning was uniformly distributed across the tidal cycle (Kolmogorov-Smirnov 1-sample test; for groups, $D=0.279, \mathrm{p}<0.001$; for pairs, $D=0.289, \mathrm{p}<0.001$; Fig. 5), the mean number of spawns being significantly higher during ebb tides than flood tides in both cases (Mann-Whitney; for groups, $U=51.5$, $\mathrm{p}<0.05$; for pairs, $U=44.0$, p $<0.05$; Fig. 5). Both group and pair spawning frequency appeared highest near the beginning of

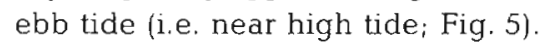

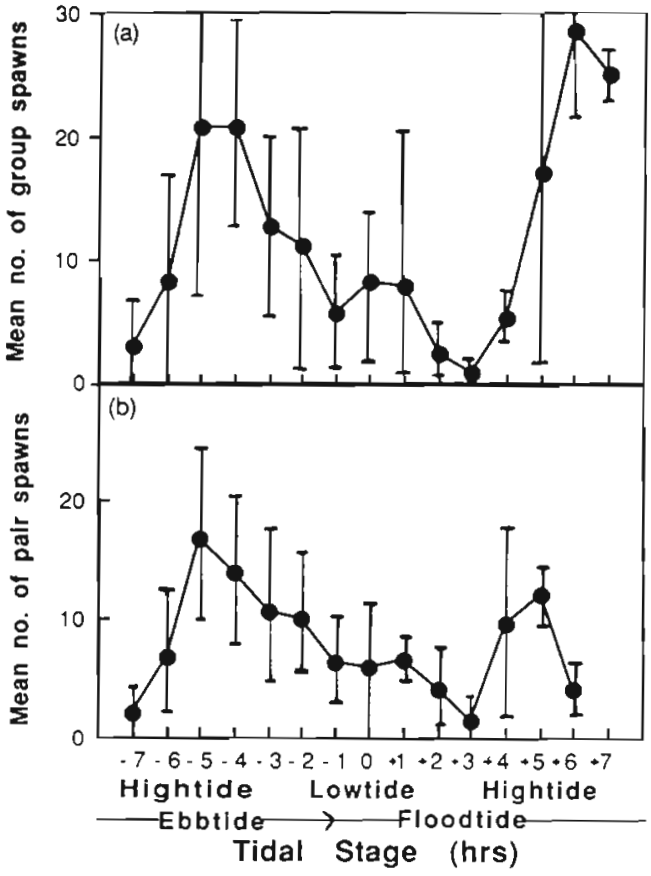

Fig. 5. Thalassoma bifasciatum. Mean number of (a) group and (b) pair spawns in each daily tidal stage for a $14 \mathrm{~d}$ period in April 1985 on North Bellairs reef, Barbados. Bars indicate $95 \%$ confidence limits

\section{Variation in currents}

Surface currents were offshore on $96 \%$ of the 94 occasions on which currents were recorded on the 2 study reefs, regardless of tidal phase. Mean current direction was west-northwest ( $x=293.0^{\circ}$ WNW). Consistently offshore surface currents have previously been recorded for Barbados west-coast fringing reefs 
by Bevan (unpubl.) and Tomascik (unpubl.). Mean surface current speed at ebb tide tended to be faster than at flood tide (ebb $0.12 \mathrm{~m} \mathrm{~s}^{-1}$, flood $0.06 \mathrm{~m} \mathrm{~s}^{-1} ; t=1.69$, $p=0.09$ ). During spring tides, mean ebb tide current speed was 5 times faster than flood tide current speed (ebb $0.21 \mathrm{~m} \mathrm{~s}^{-1}$, flood $0.04 \mathrm{~m} \mathrm{~s}^{-1} ; t=2.43, \mathrm{p}<0.02$ ). During neap tides, mean ebb tide current speed was only twice that of flood tide current speed (ebb $0.08 \mathrm{~m}$ $\mathrm{s}^{-1}$, flood $0.04 \mathrm{~m} \mathrm{~s}^{-1} ; t=2.63, \mathrm{p}<0.02$ ). Mean ebb tide current speed during spring tides tended to be faster than that during neap tides (spring $0.21 \mathrm{~m} \mathrm{~s}^{-1}$, neap $0.08 \mathrm{~m} \mathrm{~s}^{-1} ; t=1.89, \mathrm{p}=0.08$ ). The data therefore suggest that both daily and lunar spawning periodicity are such that more spawning occurs during periods of fast offshore currents than periods of slow offshore currents.

\section{Seasonal recruitment}

As determined by otolith settlement marks, recruitment of juveniles to Heron Bay reef occurred throughout the year, but was not uniformly distributed across months (Kolmogorov-Smirnov 1-sample test, $D=0.098$, $\mathrm{p}<0.01$, most recruitment occurring between June and December 1984 (Fig. 6). Spawning in 1984 occurred

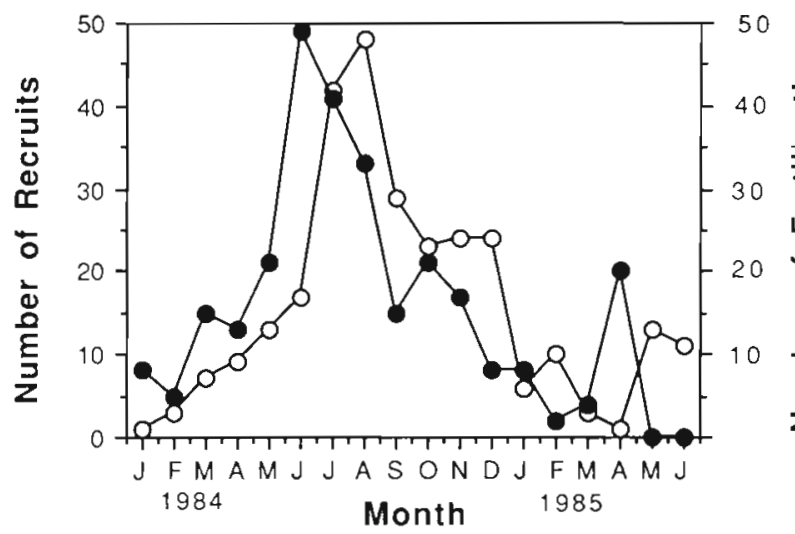

Fig. 6. Thalassoma bifasciatum. Number of (O) recruits and fertilisations vs time of the year on Heron Bay reef, Barbados

primarily between March and November (Fig. 6). Correlations between spawning and recruitment were significant when recruitment was related to spawning using time lags of 1 to $2 \mathrm{mo}$, but insignificant with time lags of $0,3,4$ and 5 mo (Table 1). A lag of 1 to 2 mo between spawning and recruitment is consistent with the larval life of Thalassoma bifasciatum in Barbados (mean $45 \mathrm{~d}$; range 33 to $64 \mathrm{~d}$; Hunt von Herbing 1988). The data therefore suggest that the principal factor driving seasonal variation in recruitment of $T$. bifasciatum in Barbados is seasonal variation in spawning.
Table 1. Thalassoma bifasciatum. Spearman's rank-correlation coefficients $\left(r_{s}\right)$ for different time lags between number of fertilisation events per month and number of recruits per month in 1984 for bluehead wrasse on Heron Bay Reef in Barbados. p: probability level

\begin{tabular}{|ccl|}
\hline Time lag $(\mathrm{mo})$ & $\mathrm{r}_{\mathrm{s}}$ & $\mathrm{p}$ \\
\hline 0 & 0.55 & 0.08 \\
1 & 0.93 & 0.001 \\
2 & 0.81 & 0.003 \\
3 & 0.49 & 0.09 \\
4 & 0.20 & 0.26 \\
5 & 0.01 & 0.44 \\
\hline
\end{tabular}

\section{Lunar recruitment}

Otolith dating was used to investigate variation in recruitment by combining individuals from all months that settled on each lunar day. Settlement was not uniform (Kolmogorov-Smirnov 1 -sample test, $D=0.17$, $p<0.01$; Fig. 7). However, when recruits were pooled

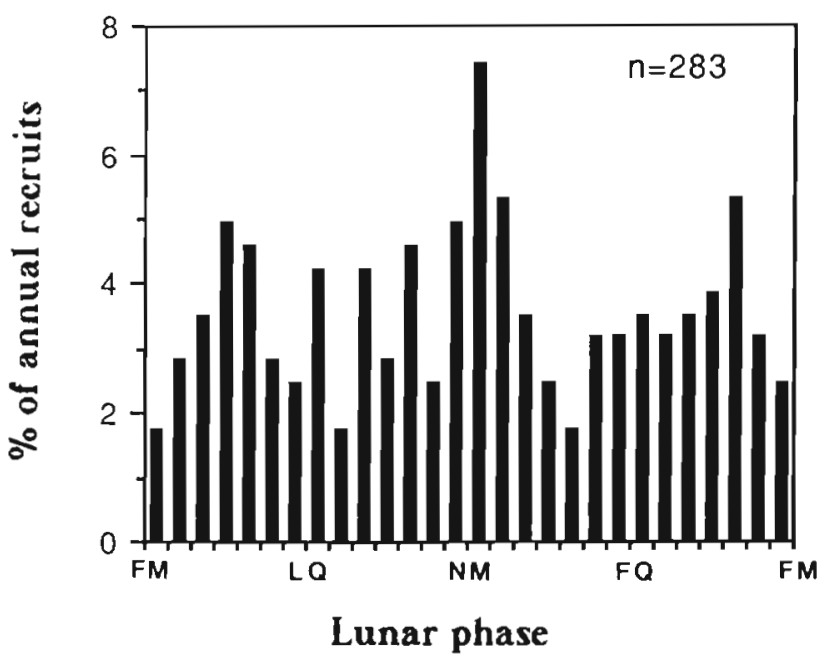

Fig. 7. Thalassoma bifasciatum. Percentage of annual recruits vs lunar phase on Heron Bay reef. Abbreviation as in Fig. 4

by lunar phase, the difference in recruitment strength between phases was not significant (Kruskal-Wallis ANOVA, $H=0.67, p>0.05$ ).

\section{Post-recruitment mortality}

Recruitment of juveniles to Heron Bay reef in 1984 occurred primarily between June and December (Fig. 6). This was reflected in the adult density on Heron Bay, which rose towards the end of 1984 to a peak in January 1985 (Fig. 8). Adult density was significantly correlated with number of recruits with a 


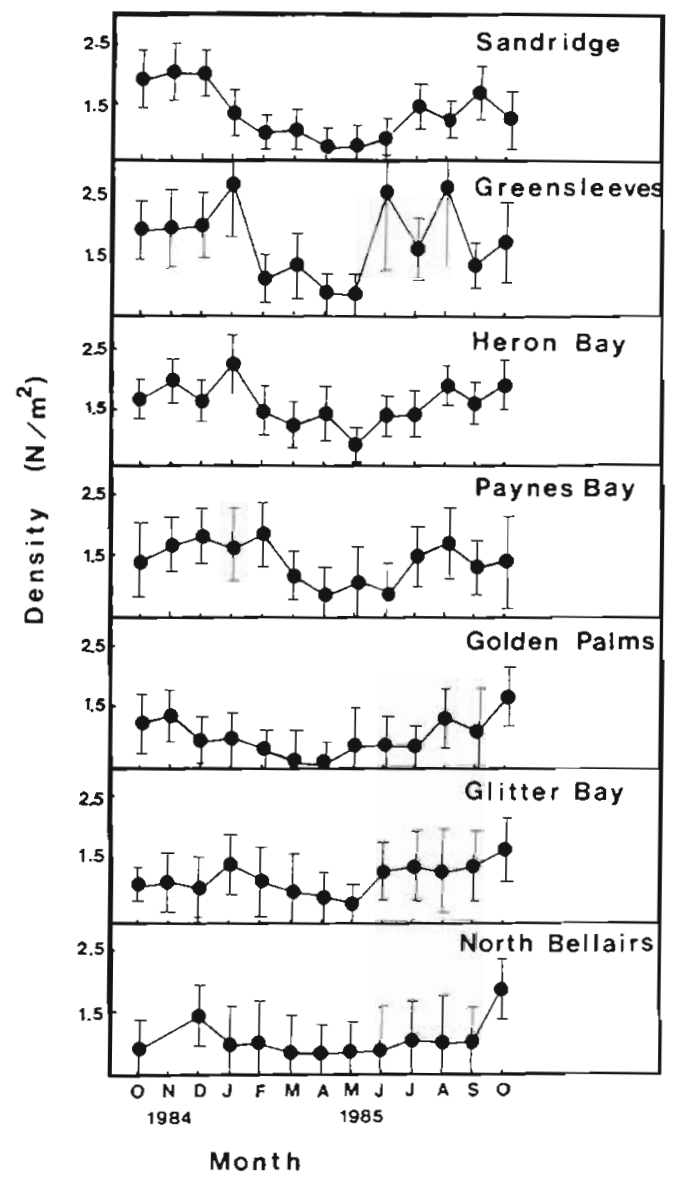

Fig. 8. Thalassoma bifasciatum. Monthly densities (no. $\mathrm{m}^{-2}$ ) vs time of year on each of 7 fringing reefs in Barbados. Bars indicate standard errors

time lag of 2 mo (Table 2). Two months is the time estimated by Victor (1986a) and confirmed in the present study for new recruits $(10 \mathrm{~mm} \mathrm{SL})$ to grow to $30 \mathrm{~mm} \mathrm{SL}$ and therefore to be detectable during density surveys. The new adult density on Heron Bay in 1985 produced by the recruitment pulse in 1984 was not maintained but fell sharply (e.g. January to February), approaching pre-recruitment levels within ca 3 mo (Fig. 8). From June 1985, densities again rose,

Table 2. Thalassoma bifasciatum. Spearman's rank-correlation coefficients $\left(r_{s}\right)$ for different time lags between number of recruits and adult density for bluehead wrasse on Heron Bay Reef in Barbados. p: probability level

\begin{tabular}{crc|}
\hline Time lag $(\mathrm{mo})$ & $\mathrm{r}_{\mathrm{s}}$ & $\mathrm{p}$ \\
\hline 0 & -0.10 & 0.77 \\
1 & 0.45 & 0.17 \\
2 & 0.76 & 0.01 \\
3 & 0.47 & 0.14 \\
4 & 0.24 & 0.49 \\
5 & 0.01 & 0.98 \\
\hline
\end{tabular}

reflecting 1985 recruitment (Fig. 8). Seasonal variation in adult density on the other study reefs was similar to that on Heron Bay. Densities peaked in December 1984/January 1985, declined until May/June 1985, and then rose again with 1985 recruitment (Fig. 8).

The post-recruitment period is considered to be December to May for Sandridge, January to May for Greensleeves, January to May for Heron Bay, February to June for Paynes Bay, November to April for Golden Palms, January to May for Glitter Bay, and December to May for North Bellairs (Fig. 8). The decline in density following recruitment is likely to result primarily from post-recruitment mortality, since the reefs are isolated and reef fish typically avoid migrating across open spaces after settlement (see Wellington \& Victor 1988). The decline probably produces a conservative estimate of mortality, since low levels of recruitment may still be occurring during this period. Monthly mortality $(\%$ dying per month) on each study reef during the postrecruitment period was significantly correlated with the density on that reef at the start of the month (Spearman's rank-correlation, $r_{s}=0.80, p<0.05$; Fig. 9a). This may suggest that post-recruitment mortality is density-dependent.

Density may not be a good index of intensity of resource competition on reefs when data are pooled from different reefs, since carrying capacities of the reefs may differ. In this study we define carrying capacity of a reef as the mean density around which density values stabilise following the recruitment pulse in any year. The values used as estimates of carrying capacity
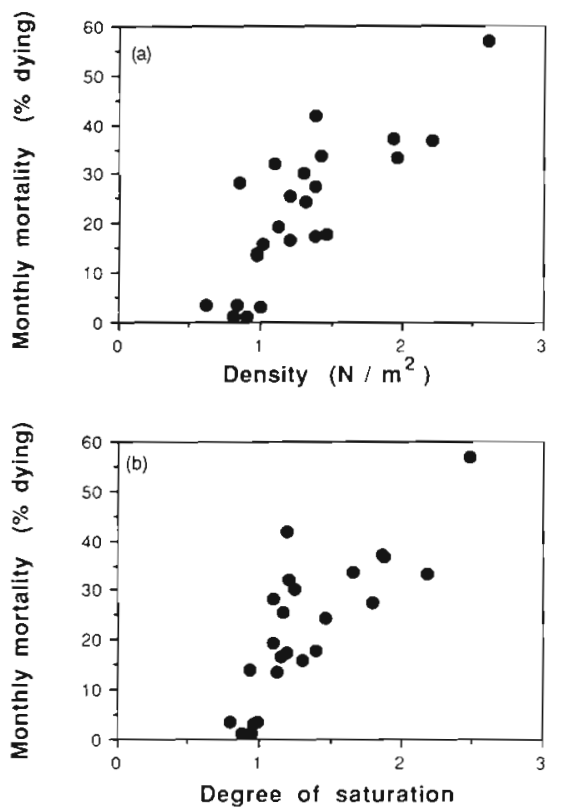

Fig. 9. Thalassoma bifasciatum. Monthly mortality rate vs (a) density at the start of the month $\left(n o . \mathrm{m}^{-2}\right.$ ) and (b) degree of saturation (density/carrying capacity), during the post-recruitment period of 1985 on 7 fringing reefs in Barbados 
are therefore the mean density between February and June for Sandridge, February and May for Greensleeves, March and June for Heron Bay, March and June for Paynes Bay, February and July for Golden Palms, March and May for Glitter Bay and March and June for North Bellairs (Fig. 8). Carrying capacity estimates are presented in Table 3 . The degree of

Table 3. Thalassoma bifasciatum. Estimates of carrying capacity for bluehead wrasse on 7 fringing reefs in Barbados and months of stable population densities (see Fig. 8)

\begin{tabular}{|llc|}
\hline Reef & $\begin{array}{c}\text { Months of } \\
\text { stable density }\end{array}$ & $\begin{array}{c}\text { Est. of carrying } \\
\text { capacity (no. m }\end{array}$ \\
\hline Sandridge & Feb-Jun & 0.90 \\
Greensleeves & Feb-May & 1.06 \\
Heron Bay & Mar-Jun & 1.17 \\
Paynes Bay & Mar-Jun & 1.04 \\
Golden Palms & Feb-Jul & 0.79 \\
Glitter Bay & Mar-May & 0.93 \\
North Bellairs & Mar-Jun & 0.84 \\
\hline
\end{tabular}

saturation on any reef in any month can therefore be estimated as the ratio of density to carrying capacity. Monthly mortality rate on each study reef during the post-recruitment period was significantly correlated with the degree of saturation on the reef at the start of the month (Spearman's rank-correlation, $r_{5}=0.80$, $p<0.05$; Fig. 9b), again suggesting that post-recruit-
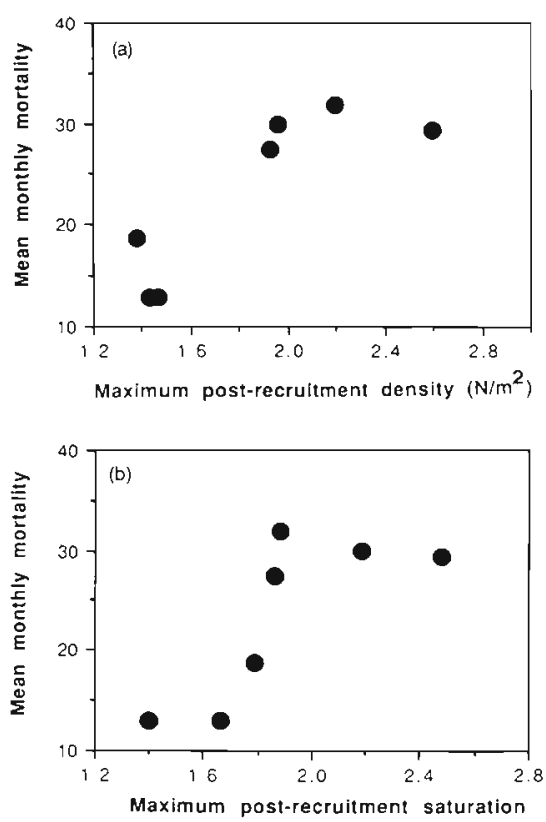

Fig. 10. Thalassoma bifasciatum. Post-recruitment mortality on a reef ( $\%$ dying $\mathrm{mo}^{-1}$ ) vs (a) peak density following recruitment on that reef (no. $\mathrm{m}^{-2}$ ) and (b) highest degree of saturation (highest density/carrying capacity), on 7 fringing reefs in Barbados ment mortality rate may be sensitive to competitive processes on the reef.

When recruitment is seasonal, age and density of recruits covary, i.e. fish are youngest when densities are highest. The correlation between mortality rate and density may therefore result simply from higher mortality in younger fish. The effect of age can be removed by use of between-reef comparisons to investigate effects of density on post-recruitment mortality. Mean monthly mortality rate throughout the post-recruitment period on each reef was signifcantly correlated with recruitment strength to that reef, i.e. with peak density following recruitment (Spearman's rank-correlation, $r_{\mathrm{s}}=$ 0.75, $\mathrm{p}<0.05$; Fig. 10a). Moreover, the maximum extent to which a reef was driven above carrying capacity by the recruitment pulse (highest density/ carrying capacity) was significantly correlated with mean monthly post-recruitment mortality on the reef $\left(\mathrm{r}_{\mathrm{s}}\right.$ $=0.93, \mathrm{p}<0.05 ;$ Fig. $10 \mathrm{~b})$. These results strongly suggest that post-recruitment mortality rate is highest when recruitment strength is greatest, i.e. post-recruitment mortality is density-dependent.

\section{DISCUSSION}

Several species of coral reef fish show seasonal variation in spawning. For example, most spawning is reported as occurring in spring or fall in the Caribbean (Munro et al. 1973, Powles 1975, Luckhurst \& Luckhurst 1977, Lobel 1978) and in summer in Australia (Russel et al. 1977, Johannes 1978, Doherty 1983a). Spawning in the bluehead wrasse in Barbados was markedly seasonal, occurring primarily between January and August in both 1984 and 1985. The pattern of seasonal spawning may vary intraspecifically with location. Roede (1972) found the highest percentage of functional gonads in bluehead wrasse during November and December and between April and June in both Puerto Rico and Curacao. Moreover, Victor (1983, 1986b) claimed that spawning of the bluehead wrasse in Panama was acyclical on both seasonal and lunar time scales, but this was based on the unpublished data of other workers (see Robertson et al. 1988).

Many reef fish show lunar or semi-lunar spawning cycles (e.g. Johannes 1978, MacFarland et al. 1985, Robertson et al. 1988, Côté \& Hunte 1989), and it is generally believed that they spawn when conditions favor the transport of eggs off reefs (Robertson \& Hoffman 1977. Tribble 1982, Doherty 1983a). This has not been tested through simultaneous measurements of spawning frequency and water movements, and Shapiro et al. (1988) have claimed that bluehead wrasse in Puerto Rico do not spawn at locations which facilitate offshore transport of eggs. In Barbados, spawning fre- 
quency of bluehead wrasse was higher around new and full moons (spring tides) than around first and last quarters (neap tides). Randall \& Randall (1963) and Roede (1972) have previously suggested that bluehead wrasse may spawn primarily around new and full moons. In addition, daily spawning of bluehead wrasse in Barbados was more frequent during ebb tides than flood tides. Surface currents on the study reefs were typically offshore ( $96 \%$ of $94 \mathrm{~d}$ monitored). They were faster at ebb tide than at flood tide, and ebb tide currents were faster during spring tides than neap tides. Both daily and lunar spawning cycles in the bluehead wrasse in Barbados therefore appear to be influenced by daily and lunar variation in the speed of offshore currents. More spawning occurred during tidal periods in which offshore currents are faster. This presumably minimises predation by reef-associated organisms (Johannes 1978). Interestingly, daily spawning was most frequent near the beginning of ebb tide, i.e. at the turn of the tide when the speed of currents may not be at their fastest for the ebb tide cycle but the subsequent duration of fast offshore currents is longest and water depth is greatest. Hunte et al. (unpubl.) found considerable variation in fertilisation rates $(\%$ eggs fertilised in spawning bouts) of bluehead wrasse in Barbados, and both Denny \& Shibata (1989) and Yund (1990) have suggested that fertilisation rates in marine organisms may be lowered by faster currents. Spawning near the beginning of ebb tide may therefore be the best compromise between maximising fertilisation rates and minimising reef-associated egg predation by spawning when both water depth and the subsequent duration of fast offshore currents is greatest.

An emerging consensus is that temporal variation in recruitment of coral reef fish results from variation in the effect of planktonic processes (e.g. Williams 1980 , Doherty 1982, 1983b, Victor 1983, 1986b, Doherty \& Williams 1988, Pitcher 1988). Recruitment of bluehead wrasse in Barbados was seasonal, occurring primarily between June and December 1984. Seasonal changes in adult density suggested a similar pattern of seasonal recruitment in 1985, and Tupper (1988) observed heaviest recruitment of bluehead wrasse to fringing reefs in Barbados between June and December in both 1987 and 1988. Recruitment of bluehead wrasse in Panama is also seasonal, occurring primarily between September and November (Victor 1986b). In Barbados, seasonal recruitment of bluehead wrasse was significantly correlated with seasonal spawning with time lags of 1 and $2 \mathrm{mo}$. The lag is consistent with the duration of the larval life of bluehead wrasse in Barbados, and suggests that seasonal variation in spawning is the principal factor driving seasonal variation in recruitment.
Semi-lunar variation in recruitment has been reported for Caribbean grunts (MacFarland et al. 1985), and unimodal variation with recruitment centered around new moon for bluehead wrasse (Victor 1983, 1984, 1986b) and damselfish (Robertson et al. 1988) in Panama. Recruitment during moonless nights may reduce fish predation on recruits (Johannes 1978, MacFarland et al. 1985, Victor 1986b, Robertson et al. 1988). Only studies by Williams (1983) and Sale (1985) reported no Iunar periodicity in reef fish recruitment, but both studies were conducted in the enclosed lagoon of One-Tree Reef, Australia. Sweatman (1985) has noted that geomorphological features of One-Tree Lagoon restrict access to recruits, and this may make detection of lunar recruitment cycles difficult (see Robertson et al. 1988). Most of these studies suggested that the recruitment variation observed resulted from variation in effects of planktonic processes, but Robertson et al. (1988) demonstrated that recruitment variation in damselfish Stegastes partitus in Panama resulted primarily from variation in spawning frequency. Note that strong selection for new moon recruitment with little flexibility in larval duration would in itself result in lunar spawning cyclicity.

Recruitment of bluehead wrasse in Barbados was not uniform across the lunar cycle, with most recruitment occurring around new moon (Fig. 7), but differences in recruitment between lunar phases were not statistically significant. This may suggest either that variation in planktonic processes was sufficient to decouple lunar recruitment from lunar spawning, or that the method used to quantify recruitment was not appropriate for detecting the lunar variation. In this study, timing of recruitment was assessed by the use of settlement marks on otoliths of captured fish $>30 \mathrm{~mm}$ SL (primarily adults). This method will only allow accurate characterisation of lunar recruitment if the original pattern of recruitment is preserved in the age distribution of adults (see Pitcher 1988). The probability that the original recruitment pattern will be obscured is higher if postrecruitment mortality is density-dependent, as is apparently the case with bluehead wrasse in Barbados.

Several studies have now suggested that coral reef fish are recruitment-limited and hence that postrecruitment mortality is not density-dependent, recruitment variation being the principal factor driving the dynamics of the demersal populations (e.g. Williams 1980, Doherty 1982, 1983b, Victor 1983, 1986b, Doherty \& Williams 1988, Pitcher 1988). However, Hunte \& Côté (1989) have recently suggested that the population dynamics of blennies Ophioblennius atlanticus in Barbados are strongly influenced by conspecific interactions following recruitment, i.e. that blennies in Barbados may be 'space-limited'. Smith (1978), Gladfelter \& Gladfelter (1979), Shulman $(1984,1985)$ and 
Jones (1987) have all previously stressed the importance of post-recruitment processes in influencing adult population dynamics of reef fish. In this study, population densities of the bluehead wrasse had returned to pre-recruitment levels within 3 mo of the seasonal recruitment. Monthly percentages of wrasses dying on each reef in the post-recruitment period were correlated with population density on the reef at the start of the month. This may suggest that post-recruitment mortality is density-dependent, but it could result from the covariance of density with age. As Victor (1986b) has emphasised, when recruitment is seasonal age and density of fish covary, and what appears to be density-dependent mortality may simply result from higher mortality in younger fish. However, the mean monthly mortality rate of bluehead wrasse over the post-recruitment period on each study reef in Barbados was significantly correlated with recruitment strength to that reef. This strongly suggests that post-recruitment mortality was density-dependent.

A comparison of the present results with those on bluehead wrasse in Panama (Victor 1983, 1986b) makes it evident that a species can be limited primarily by planktonic processes at one location (recruitmentlimited) and primarily by post-recruitment processes at another (space-limited). This difference in population dynamics of bluehead wrasse in Barbados and Panama is consistent with the observation that the mean population density in Barbados is 2 to 3 times that in Panama (Warner \& Hoffman 1980, Victor 1986b). The lower density in Panama may imply lower recruitment rates. Interestingly, the studies of damselfish populations which support recruitment-limitation (Williams 1980, Doherty $1982,1983 \mathrm{~b}$ ) were conducted at One-Tree Island. These reefs have particularly low damselfish density and, as previously stated, very low recruitment rates (Thresher 1984, Sweatman 1985, Sale \& Ferrell 1989).

As the number of studies of reef fish population dynamics increases, it is becoming evident that a dichotomy between space-limitation and recruitmentlimitation as mechanisms controlling reef fish population size is too extreme. Pure recruitment-limitation and pure space-limitation characteristics should best be perceived as extremes of a continuum. Characteristics of different species may influence the position they occupy on the continuum. Moreover, the position occupied by a given species may vary markedly with local oceanographic conditions. At some locations, conditions may drive a species into cycles of high recruitment, high density, and high larval production, i.e. space-limited characteristics may be dominant. At other locations, a species may be held in cycles of low recruitment, low density, and low larval production, i.e. recruitment-limited characteristics may be dominant. Most studies of reef fish on Caribbean islands (Shul- man et al. 1983, Shulman 1984, 1985, Tupper 1988 Hunte \& Côté 1989, present study) have produced results suggestive of space-limitation. Oceanographic conditions on the leeward side of small oceanic islands (the 'island mass effect') may support the retention of fish larvae (e.g. Powles 1975), thereby enhancing recruitment to nearshore reefs. Such locations may typically be less susceptible to recruitment-limitation than reef areas where oceanographic conditions do not favor larval retention and subsequent recruitment (e.g. Panama and One-Tree Island, Australia).

Acknowledgements. We thank L.-A. Giraldeau for participation in the work on diurnal spawning patterns, $M$. Tupper, $D$. Younglao and L. Parker for assistance in the field, and L. A. Vermeer, J. Dickie and $Z$. Tooze for assistance in manuscript preparation. The work was supported by an Operating Grant from Natural Sciences and Engineering Research Council of Canada to W. H

\section{LITERATURE CITED}

Brothers, E. B., Matthews, C. P., Lasker, R. (1976). Daily growth increments in otoliths from larval and adult fishes Fish Bull. U.S. 74: 1-8

Brothers, E. B., Williams, D., McB., Sale, P. F. (1983). Length of larval life in twelve families of fishes at 'One-Tree Lagoon' Great Barrier Reef, Australia. Mar. Biol. 76: 319-324

Côté, I. M., Hunte, W. (1989). Male and female mate choice in the redlip blenny: why bigger is better. Anim. Behav. 38: $78-88$

Denny, M. W., Shibata, M. F. (1989). Consequences of surf zone turbulence for settlement and external fertilisation. Am. Nat. 134: 859-889

Doherty, P. J. (1982). Some effects of density on the juveniles ot two species of tropical territorial damselfish. J. exp. mar. Biol. Ecol. 65: 249-261

Doherty, P. J. (1983a). Diel, lunar and seasonal rhythms in the reproduction of two tropical damselfishes: Pomacentrus flavicauda and P. wardi. Mar. Biol. 75: 215-224

Doherty, P. J. (1983b). Tropical territorial damselfishes: is density limited by aggression or recruitment? Ecology 64 : $176-190$

Doherty, P. J., Williams, D. McB. (1988). The replenishment of coral reef fish populations. Oceanogr. mar. Biol. A. Rev. 26: $487-551$

Gladfelter, N. B., Gladfelter, E. H. (1979). Fish community structure as a function of habitat structure on West Indian patch reefs. Rev. Biol. Trop. 26: 65-84

Hunt von Herbing, I. (1988). Reprodiction and recruitment in the bluehead wrasse, Thalassoma bifasciatum, in Barbados. M. Sc. thesis. McGill University, Montreal

Hunte, W. Côté, I. M. (1989). Recruitment in the redlip blenny Ophioblennius atlanticus: is space limiting? Coral Reefs 8: $45-50$

Johannes, R. E. (1978). Reproductive strategies of coastal marine fishes in the tropics. Envir. Biol. Fish 3: 65-84

Jones, G. P. (1987). Competitive interactions among adults and juveniles in a coral reef fish. Ecology 68: 1534-1547

Keener, P., Johnson, G. D., Stender, B. W., Brothers, E. B., Beatty, H. R. (1988). Ingress of postlarval gag, Mycteroperca microlepis (Pisces: Serranidae), through a South Carolina barrier island inlet. Bull. mar. Sci. 42 (3) : 376-396 
Lobel, P. S. (1978). Diel, lunar and seasonal periodicity in the reproductive behavior of the pomecentrid fish Centropyge potteri, and some other reef fishes. Pacif. Sci. 32: 193-207

Luckhurst, B. E., Luckhurst, K. (1977). Recruitment patterns of coral reef fishes on the fringing reef of Curacao, Netherlands Antilles. Can. J. Zool. 55: 681-689

McFarland, W. N., Brothers, E. B., Ogden, J. C., Shulman, M. J., Bermingham, E. L., Kotchian-Prentiss, N. M. (1985). Recruitment patterns in young french grunts Haemulon flavolineatum (Family Haemulonidae), at St. Croix, U.S.V.I. Fish Bull. U.S. 83: 413-426

Miller, J. M., Hunte, W. (1987). Effective area fished by Antillean fish traps. Bull. mar. Sci. 40: 484-493

Munro, J. L., Gaut, V. G., Thompson, R., Reeson, P. H. (1973). The spawning seasons of Carribbean reef fishes. J. Fish. Biol. 5: 69-84

Pitcher, C. R. (1988). Validation of a technique for reconstructing daily patterns in the recruitment of coral reef damselfish. Coral Reefs 7: 105-111

Powles, H. W (1975). Abundance, seasonality, distribution and aspects of the ecology of some larval fishes off Barbados. Ph. $\mathrm{D}$. thesis. McGill University, Montreal

Randall, J. E., Randall, H. A. (1963). The spawning and early development of the Atlantic parrotfish Sparisoma rupbripinne with notes on other scarid and labrid fishes. Zoologica 48: 49-60

Robertson, D. R., Hoffman, S. G. (1977). The roles of female mate choice and predation in the mating system of some tropical labroid fishes. Z. Tierpsychol. 45: 298-320

Robertson, D. R., Green, D. G., Victor, B. C. (1988). Temporal coupling of production and recruitment of larvae of a Caribbean reef fish. Ecology 69: 370-381

Roede, M. J. (1972). Colour as related to size, sex and behavoir in seven Caribbean labrid fish species (genera Thalassomá, Halichoeres and Hemipterinotus). Stud. Fauna Curaçao 138: 1-264

Russell, B. C., Anderson, G. R. V., Talbot, F. H. (1977). Seasonality and recruitment of coral reef fishes. Aust. J. mar. Freshwat. Res. 28: 521-528

Sale, P. F. (1985). Patterns of recruitment in coral reef fishes Proc. 5th Int. Coral Reef Congress, Tahiti, Vol. 5, p. 391-396

Sale, P. F., Ferrell, D. J. (1989). Early survivorship of juvenile and coral reef fishes. Coral Reefs 7: 3-14

Shapiro, D. Y., Hensley, D. A., Appeldoorn, R. A. (1988). Pelagic spawning and egg transport in coral-reef fishes: a skeptical overview. Envir. Biol. Fish. 22: 3-14

Shulman, M. J. (1984). Resource limitation and recruitment patterns in a coral reef fish assemblage. J. exp. mar. Biol. Ecol. 74: 85-109

Shulman, M. J. (1985). Recruitment of coral reef fishes: effects of distribution of predators and shelter. Ecology 66: 1056-1066

This article was submitted to the editor
Shulman, M. J., Ogden, J. C., Ebersole, J. P., McFarland, W. N., Miller, S. L., Wolf, N. G. (1983). Priority effects in the recruitment of juvenile coral reef fishes. Ecology 64: $1508-1513$

Smith, C. L. (1978). Coral reef fish communities: a compromise view. Envir Biol. Fish. 3: 107-128

Sweatman, H. P. A. (1985). Influence of adults of some coral reef fishes on larval recruitment. Ecol. Monogr. 55: $469-485$

Thresher, R. E. (1984). Reproduction in reef fishes. T F. H. Publications, Neptune City, New Jersey

Tribble, G. W. (1982). Social organisation, patterns of sexuality and behavior of the wrasse Coris dorsomaculata at Miyake-Jima, Japan. Envir. Biol. Fish. 7: 29-38

Tupper, M. H. (1988). Recruitment and assemblage structure of reef tish in Barbados, W.I. M.Sc. thesis, McGill University, Montreal

Victor, B. C. (1982). Daily otolith increments and recruitment in two coral reef wrasses Thalassoma bifasciatum and Haichoeres bivitatus. Mar. Biol. 71: 203-208

Victor, B. C. (1983). Recruitment and population dynamics of a coral reef fish. Science 219: 419-420

Victor, B. C. (1984). Coral reef fish larvae: patch size estimation and mixing in the plankton. Limnol. Oceangr. 29: $1116-1119$

Victor, B. C. (1986a). Duration of the planktonic larval stage of one hundred species of Pacific and Atlantic wrasses. Mar. Biol. 90: 317-326

Victor, B. C. (1986b). Larval settlement and juvenile mortality in a recruitment-limited coral reef fish population. Ecol. Monogr. 56: 145-160

Warner, R. R., Hoffman, S. G. (1980). Local population size as a determinant of mating system and sexual composition in two tropical marine fishes (Thalassoma spp.). Evolution 34: $508-518$

Warner, R. R., Robertson, D. R., Leigh, Jr E. G. (1975). Sex change and sexual selcetion. Science 190: 633-638

Wellington, G. M., Victor, B. C. (1988). Variation in components of reproductive success in an undersaturated population of coral-reef damselfish: a field perspective. Am. Nat. 131: 588-601

Wellington, G. M., Victor, B. C. (1989). Planktonic larval duration of 100 species of Pacific and Atlantic damselfishes (Pomacentridae). Mar. Biol. 101: 557-567

Williams, D. McB. (1980). Dynamics of the pomacentrid community on small patch reefs in the One-Tree Lagoon (GBR). Bull. mar. Sci. 30: 159-170

Williams, D. MCB. (1983). Daily, monthly and yearly variability in recruitment of a guild of coral reef fishes. Mar. Ecol. Prog. Ser. 10: 231-237

Yund, P. O. (1990). An in situ measurement of sperm dispersal in a colonial marine hydroid. J. exp. Zool. 253: 102-106

Manuscript first received: May 30, 1990

Revised version accepted: March 1, 1991 